\section{A DÍJTÁMOGATOTT NÖVÉNYBIZTOSÍTÁS AZ ELSÖ ÖT ÉV TÜKRÉBEN}

Füzesi Dániel (Groupama Biztositó mezögazdasági termékmenedzser, a MABISZ Mezögazdasági Bizottságának elnöke)

\section{ÖSSZEFOGLALÓ}

A mezőgazdaság kockázatainak kezelése Magyarországon az elmúlt években egyre nagyobb hangsúlyt kapott, a mezőgazdasági kockázatkezelési rendszer folyamatosan bővült, fejlődött. Ennek egyik jelentős eredményeként 2012-ben új, kétpilléres mezőgazdasági kockázatkezelési rendszer került bevezetésre, melynek 2. pillérét a biztosítási dítámogatás alkotja. A biztosítási dijtámogatás keretében a mezőgazdasági termelők a támogatott konstrukcióban megkötött növénybiztosítások dijához kapnak támogatást.

A növénybiztosítási díjtámogatás bevezetése a mezőgazdasági termelők és a biztosítók számára egyaránt ösztönző hatású volt, hiszen a termelő számára a biztosítási díj megfizetése könnyebbé vált, új termelők is kötnek biztosítást a támogatásnak köszönhetően, a biztosítási piac bővült. A biztosítási dítámogatás a korábban elérhető piaci biztosítási konstrukcióknál kedvezőbb feltételek kialakítását tette lehetővé. Jelen cikk ezen intézkedés elmúlt 5 évének az eredményeit foglalja össze.

\section{SUMMARY}

The risk management of the agricultural sector became more and more important, and the risk management scheme has enlarged and developed. As a significant result of it, a new two-pillar risk management scheme was introduced in 2012. Its second pillar is the premium support to crop and plant insurances.

The introduction of the crop and plant insurance premium support had a motivating effect both for the farmers and insurance companies: farmers can pay the insurance premium more easily, and there are also new farmers who can take out insurance due to the support so the insurance market has enlarged. The insurance premium support made it possible to work up more favourable conditions than the earlier market insurance provisions.

Kulcsszavak: mezőgazdasági biztosítás

Keywords: agricultural insurance

JEL: G22, Q10

DOI: $10.18530 /$ BK.2017.2.76

http://dx.doi.org/1018530/BK.2017.2.76

\section{A magyar rendszer bevezetése}

A 2011. évi CLXVIII törvény a „mezőgazdasági termelést érintő időjárási és más természeti kockázatok kezeléséról” (továbbiakban Mkk.) és az azt kiegészítő 143/2011. (XII.23.) számú FM rendelet teremtette meg az Unió által jóváhagyott Mezőgazdasági Kockázatkezelési Rendszert (MKR). E kockázatkezelési rendszer két pillérből áll, melyek a Kárenyhítési Rendszer (I. Pillér) és a Növénybiztosítások Díjtámogatása (II. Pillér). Ezzel a jogszabály- és intézkedéscsomaggal Magyarország kormánya meghonosította azt a nemzetközi gyakorlatot (Felkai - Varga, 2010), mellyel a mezőgazdasági termelőknek termeléstől független, hatékony (Gazdag - Tanczné, 2017) támogatási eszközként, az öngondoskodás fokozásával, a biztosítótársaságok közreműködésével kezeli a növénytermesztést sújtó időjárási hatások káros következményeit.

\section{Különös nehézséget okozott az uniós elöírások, a magyar} piaci gyakorlat és a termelöi érdekek összehangolása.

Az intézkedés bevezetését hosszas munka előzte meg. A Földművelésügyi Minisztérium(FM) vezetésével 2010 öszén alakult meg az a munkacsoport, melyben a Minisztérium munkatársain kívül az Agrárgazdasági Kutató Intézet (AKI), az Országos Meteorológiai Szolgálat (OMSZ), különböző termelői szervezetek (pl.: Gabonatermesztők Országos Szövetsége) mellett a magyar növénybiztosítási piac szakemberei is helyet kaptak. A közel másfél éves munka során alapvetö szempont volt, hogy a dijtámogatott termékeknek olyan kockázatokat is kezelniük kell, mely fedezetekre a korábbi biztosítói gyakorlat nem terjedt ki. Így vált biztosítható kockázattá az aszály, a felhőszakadás, az árvíz és a tavaszi fagy. A munka során különös nehézséget okozott az uniós előírások, a magyar piaci gyakorlat és a termelői érdekek összehangolása. Példának okáért brüsszeli elöírás, hogy csak az üzemi hozamérték 30 százalékát meghaladó károkra fedezetet nyújtó biztosítási szerződés díja támogatható. Ez a gyakorlatban azt jelenti, hogy ha egy magyar mezőgazdasági termelőnek az az évi termésének 25 százalékát elpusztító jégkára van, nem kaphatna kártérítést, holott a növénytermesztés önköltsége - technológiától függően - 80-90 százalék közötti. Ezért alakultak ki a támogatott szerződések magas „kárküszöbét” kiegészítő biztosítási konstrukciók, melyek a szokásos piaci gyakorlat szerint már 5 százalék kár felett térítenek a termelőknek.

A 2012. évi bevezetést követő harmadikévben már kevésnek bizonyult a rendelkezésreálló támogatási forrás, ezért életbe lépett a támogatási intenzitást mérséklő mechanizmus. Az eredeti jogalkotói szándék szerint a korábbi biztosítói fedezetvállalással el nem ért növénytermesztői rétegeket, korábban nem vállalt kockázatok fedezetét nagyobb támogatással lehet a rendszerbe integrálni, ezért került rögzítésre a különböző támogatott „termékek” eltérő támogatásintenzitása túligénylés esetén. Ezzel biztosított volt, hogy a korai években a maximális támogatással (65\%) gyorsan, teljesen kihasználhatóvá váljon az elkülönített forrás, majd a fokozatos bővüléssel a hangsúly a csomagbiztosítások és a drágábban művelhető, munkaerő-igényesebb kertészeti kultúrák felé tolódhasson. 
2016-ban, a rendszer müködésének ötödik évében már csak az „A” „összkockázatú” csomagbiztosítást választó termelők kaptak 65 százalékos támogatást, az egyéb termékek után lényegesen kisebb, 40-43 százalék közötti támogatásban részesültek.

Mindeközben a rendszer fokozatosan változik. Egyrészt a fokozódó időjárási szélsőségek megjelenésével új termelői igények jelennek meg, melyeket a rendszerbe integrálni szükséges. Így került be az őszi fagykockázat a támogatással biztosítható kockázatok körébe. Másrészt az uniós agrárpolitika változásából eredő kihívásoknak is mindenkor meg kell felelni. A 2013-ban bevezetett új Közös Agrárpolitika (KAP) a biztosítási dijtámogatás intézményét áthelyezte az EMVA tengelyre, ezért a korábban jóváhagyott magyar intézkedést a Vidékfejlesztési Programba kellett integrálni, melynek brüsszeli akkreditációja különösen nehézkesen haladt, ez veszélybe sorolta a fiatal intézkedés 2015. évi működését (és létét). Ennek áthidalására az FM kezdeményezésére „átmeneti intézkedésként”, tisztán hazai forrásból működhetett tovább a „jogcím”, szinte változatlan feltételek mellett, úgy, hogy a termelők - mint a támogatás kedvezményezettjei - alig vettek észre valamit a változásból.

A díjtámogatás alapja egyrészt a biztosítási szerződés, másrészt a termelő Egységes Kérelme, melyben idén 41 különböző jogcímre igényelhet támogatást. Ebből a biztosítási díjtámogatás igénylése az egyik legegyszerűbb, pusztán egy „kattintás” szükséges. Ami a termelő számára egyszerűsítés, az a biztosító számára jelent többletmunkát. Jelenleg ötféle adatcsere zajlik a biztosítótársaságok és a hatóságok között, melyek végén a biztosító az ügyfél (termelő) Egységes Kérelmében megjelölt növényekre, kockázatviselési helyekre (MEPAR blokkazonosító szerint), az abban megjelölt területeket nem meghaladóan módosított biztosítási szerződés adatait átadja a kifizető hatóságnak (MÁK), ennek alapján a hatóság megállapítja elöször az igénylések volumene függvényében a visszaosztással korrigált támogatási intenzitást, majd intézkedik a dítámogatásnak a termelő részére történő kifizetéséről.

\section{Az intézkedés hatása}

A mezőgazdasági biztosítások 85 százaléka növénybiztosítás, így a növénybiztosítások eredménye meghatározó a teljes ágazat számára is. Az intézkedés eredményét azonban nem lehet a növénybiztosításokat befolyásoló egyéb hatásoktól függetlenül értékelni.

\section{Az intézkedés eredményét nem lehet a növénybiztosításokat befolyásoló egyéb hatásoktól függetlenül értékelni.}

Ezek egyike az időjárás változása, illetve változékonyságának fokozódása, ami egyértelmü trend, a klímaváltozás első kézzelfogható jele. Történeti vetületben (nem túl messzire visszatekintve) tudjuk, hogy az előző évtized harmadik dekádjában évről évre nagyobb károkat okoztak a jégesők, a viharok, melyek „megkoronázásaként” következett be a 2010. június 18-i „Mezöhegyesi-jégverés", melynek káraira az évi növénybiztosítási díjbevétel több mint felét fizették ki a biztosítók. És ez csak egy volt a 2010. évi természeti csapások közül. Ezek a körülmények vezettek oda, hogy 2011-ben a mezőgazdasági biztosítási piac egyik régi szereplöje felszámolta ez irányú tevékenységét, hiába folytak már az egyeztetések a dijtámogatás bevezetéséről.

A másik fontos tényező a terményárak alakulása, ami közvetlen hatással van a biztosítási díjakra, így a volumenre is. A világgazdasági hatások okán 2012-ben az egekbe szöktek a gabonaárak, átlagosan 30 százalék feletti gabonaár-emelkedés volt tapasztalható az előző évhez képest, a 2009. évi átlagárakhoz viszonyítva viszont 300 százalékos árszint alakult ki 2012-ben (Agrárpiaci jelentések, AKI). Hozzá kell tenni, hogy a biztosítási szerződésekben a szereplők „józanul” gondolkodnak, és a terménypiaci áringadozás mérsékelten és később jelenik meg a szerződésekben, így a kilengés csak mintegy 10-15 százalék biztosításiösszeg-emelkedést jelentett a következő évben, majd két év elteltével a 2011. évi árszinteken stabilizálódott.

A 2010-es évek elején (2010 után!) azonban biztosítói szempontból kedvező időjárási körülmények adódtak, melyeket a dijtámogatás bevezetése, a terményárak emelkedése tovább javított, így a 2012-2015. évek között általánosan jó mezőgazdasági biztosítási eredmények születtek.

2016-ban már lényegesen visszafogottabb eredményeket mutatnak a számok, van társaság, melynek ágazati mutatója negatívba fordult!

Az ágazati eredmények, mutatók között mélyre kell ásni, hogy a díjtámogatás közvetlen eredményét, hatásait lássuk. Az AKI éves számadásai a Mezőgazdasági Kockázatkezelési Rendszer előző éves működéséről és a MABISZ tagozati munkájának ismeretében a következő eredményekről beszélhetünk.

Az eredeti jogalkotói szándék szerint tömegesen jelentek meg biztosítási szerződéskötési igényükkel a gyümölcstermesztők, különösen a szakosodott kistermelők.

Szintén a jogalkotói szándék szerint való, hogy azösszkockázatú fedezetet választó szántóföldi gazdálkodók is egyre többen vannak, bár ehhez szükséges volt, hogy a biztosítók a szántóföldi kultúrák esetében az összkockázatú termék díját a fö kockázatok szerinti díjszintre engedjék.

Szántóföldi kistermelői körökben azonban az intézkedés közvetlen hatásaként ez ideig nem született egyértelmű áttörés, azaz szántóföldi kistermelők körében nem nőtt jelentősen a penetráció. Ennek egyik oka, hogy a kistermelők (részben vagy egészben) integráció keretében végzik munkájukat, és a díjtámogatási rendszer adminisztrációs nehézségei okán a nagy termeltető rendszerek általánosan csak a tavalyi évben tették elérhetővé a díjtámogatott módozatokat termelőik számára, ezek is „csak” az alap jég- és tűzfedezetet tartalmazó konstrukciók. Másik ok a magyar kistermelői réteg rendkívüli elaprózottsága. Az AKI és a KSH kutatásaiból (Gazdaságszerkezeti Összeírás 2013, 2016) kiolvasható, hogy a szántóterületek (4,6 millió ha) 52 százalékát az összesen 200 ha feletti földterületen gazdálkodó (nagy ) termelő használja, akik viszont az összes gazdálkodó 455 ezer tagú közösségéből csak 0,8 százalékot képviselnek. Ezzel szemben a kistermelők, akik 5 hektárnál kisebb területen gazdálkodnak, a földterületek 5,4 százalékát használják, számarányukat tekintve viszont 83 százalékot képviselnek. (Némiképpen árnyalja a különböző statisztikák összevethetőségét, hogy 2016-ban Egységes Kérelemben földalapú támogatást csak 178 ezer igénylő adott be, a KSH által nyilvántartott földterületek 108,8\%-ára.) Ebből az elaprózottságból ered a következő probléma, az üzletkötői hálózat nagytermelőkre specializálódása. A biztosítók és értékesítési partnereik hálózata a nagytermelőkre 
koncentrál, és jellemzően nem tudja megszólítani az 5 hektár alatti kistermelőket. Mindezek ellenére indirekt módon kimutatható a penetráció növekedése, hiszen a terményárak felfutása megelözte a díjtámogatott termékek felfutását, melyek jelentős növekedése 2014-ben indult, mikor a terményárindex már csökkenő tendenciát mutatott, ám az ágazati dijbevételeken ez nem látszott, tehát a penetráció növekedése kompenzálta a terményárcsökkenés hatását.

\section{7-ben is növekszik a díjtámogatott terméket választó}

termelők sokasága, ami mérsékelheti a támogatási intenzitást.

Az utóbbi évek trendjét követve 2017-ben is növekszik a dijtámogatott terméket választó termelők sokasága, ami mérsékelheti a támogatási intenzitást. A piaci becslések mindegyike szerint szükség lesz az „A” csomagbiztosítás támogatási intenzitásának csökkentésére, akár az első minimumig (55\%), és a „C” módozat második fokozatú visszavágására - 40 százalék alá, hacsak további forrásbővítésre nem kerül sor.

Egyértelmü következménye a díjtámogatásnak a biztosítótársaságok menedzsmentjének érdeklődése a mezőgazdaság iránt. Mint kiemelt nemzetgazdasági ágazat, a mezőgazdaság a biztosítókon belül is - a közelmúlt pozitív eredményeinek is köszönhetően - jellemzően megkülönböztetett, legalábbis a volumenéből következőnél nagyobb figyelmet kap. Emellett a határon átnyúló szolgáltatással Magyarországon az ezredforduló után induló osztrák növénybiztosító az utóbbi években jelentősen megnövelte részesedését, majd fióktelep nyitásával immár negyedik szereplővé avanzsált. A piaci élénkülés ugyanakkor a szakmai szempontok maximális figyelembevételével párosulva nemcsak díjverseny formájában jelenik meg, hanem egyre fokozza a szolgáltatási versenyt. A társaságok fokozatosan a termelői igényekre szabják feltételeiket - ideértve mind a támogatott konstrukciókat, mind a támogatott szerződések mellé kínált „kiegészíto” termékeket -, így egyre nagyobbak az eltérések a jogszabályok diszpozitív rendelkezései révén a néhány évvel korábbi gyakorlathoz képest, amikor minden szereplő igyekezett az ismeretlen kockázatok okán a jogszabályi kötöttségek minimumára fedezetet vállalni. Mindemellett a dítámogatott szerződések arányának növekedési dinamikája lassul, ami a forrás szűkösségének közvetlen következménye.

\section{A jövőbeli fejlesztési irányokról}

A nemzetközi gyakorlat is azt mutatja, amit Magyarországon tapasztalunk: egy ilyen rendszert folyamatosan fejleszteni szükséges, követni kell a mezőgazdasági trendeket, a piaci kihívásokat, termelői elvárásokat, és nem utolsósorban az időjárás változása jelentette kihívásokat.

A tavalyi tényadatok és az idei évi prognózisok alapján választ kell találni a forrás szűkössége jelentette kihívásra. A támogatási jogcím sikerességét látva bővíteni kell a rendelkezésre álló keretet, amennyiben a penetráció további fokozása a cél.

A mezőgazdaságnak a növénytermesztés melletti - gyakran mostohagyermekként kezelt - ágazata az állattenyésztés. A 2016 őszén kirobbant madárinfluenza-járvány rávilágított az állattenyésztés kockázataira, a termelői öngondoskodás hiányára. Hiába van ugyanis a nagyobb biztosítóknak élő terméke a járványos megbetegedések okozta kockázatok miatti költségek részleges térítésére, a baromfitartók mindössze 2 százaléka kötött ilyen szerződést, de az elemi károkra fedezetet nyújtó termékek esetében is alacsony a penetráció. Mindezek tükrében munkacsoport alakult az állatbiztosítások dijtámogatásának bevezetésére 2017 tavaszán.

A tengeren túli trendeket figyelemmel kísérve elmondhatjuk, hogy a hétévente megújuló KAP-nak hosszú távon egyre bővülő eleme lesz a kockázatkezelés, azon belül pedig a biztosítási díjámogatás. A biztosítói tapasztalatok birtokában a termelői elvárásokra specializált szegmens és kiegészítő termékek megjelenése várható, kiteljesítve a szolgáltatói versenyt.

\section{Összegzés}

Termelői szemszögből a növénybiztosítási dítámogatás bevezetésével lehetőség nyílt korábban nem biztosítható kockázatokra való fedezet vásárlására, ráadásul mindezt elérhető módon, hiszen a támogatás révén a biztosítókáltal elkért kockázatarányos díjak megfizethetővé váltak a termelők számára. Biztos haszonélvezői a rendszernek azok a mezőgazdasági gazdálkodók, akik a biztosításra a díjtámogatás előtt is áldoztak a tudatos öngondoskodást választva, hiszen a korábbi ráfordításuk jelentősen mérséklődött a támogatás következtében.

Azállamigazgatás számára az intézkedés hasznossága a mezőgazdasági kockázatok kezelésében való jelentős biztosítói szerepvállalás miatt megkérdőjelezhetetlen, hiszen a támogatásra elkülönített forrás ráfordításával a törvény szabta keretek között a biztosítótársaságokra helyezi az egyik legfontosabb nemzetgazdasági ágazat klimatikus eredetű kárait.

Biztosítói megközelítésből pedig a támogatásnak köszönhetően megfizethetővé vált kockázatok fedezetbe vonásával és a biztosítási díjakat korábban drágának tartó kistermelők megjelenésével piacbővülés, illetve ágazati díjbevétel-növekedés történt, mely kompenzálni tudta a terményárak csökkenését is, és emelkedő pályára állította a korábban stagnáló ágazatot.

\section{IRODALOMJEGYZÉK}

2011. évi CLXVIII. törvény a mezögazdasági termelést érintő időjárási és más természeti kockázatok kezelésér 143/2011.(XII.23.) FM rendelet a mezỏgazdasági biztositás dijához nyúitott támogatás igénybevételi feltételeiröl 143/2011.(XII.23.) FM rendelet a mezőgazdasági biztositís dijához nyúitott támogatás igénybevételi feltételeiről
19/2014.(X.29.) FM rendelet a mezőgazdasági biztositás dijhoz nyujtott támogatásról Az Európai Parlament és a Tanács 1305/2013/EU rendelete az Európai Mezőgazdasági Vidékfejleszzési Alapból (EMVA) nyújtandó vidékfejlesztési támogatásról Felhivás a mezögazdasági biztositás dijához nyúttott támogatásról (VP3-17.1.1-16) Agrargazdasagi Kutató Intézet - Az agrar-kocḱázatkezelesi rendszer müködésének értékelése (és nemzetközi gyakorlata, Agrárgazdasági Kutató Intézet (AKI)

Gazdag Gyula - Tanczné Óvári Csilla (2017): Indokolt az optimizmus a dijtámogatott növénybiztositások kapcsán (Biztositás és Kockázat IV. évfolyam 2. szám)

Kovacs Gabor (et al.). Kockäzatok es Kockazaatkezeles a mezögazdaságban; AKI 2009 